\title{
The Linguistic and Rhetorical Legacy of the Prague Spring: Reading the Czechoslovak Communist Party Daily, Rudé právo, from the Late 1980s
}

This study uses a corpus-informed lexicological approach to analyse texts published in the Czechoslovak Communist party daily Rudé právo during the final years of Communist rule in Czechoslovakia. the analysis aims to uncover how far such texts represented a departure from or a reaffirmation of the norms of the pre-Gorbachev era and, in particular, the role that they played in the party's attempt to control interpretations of the 1968 Prague Spring. the investigation also considers ways in which the texts sought to construct a 'new' reality in the light of the changes in the Soviet Union and other Warsaw pact countries. the article maintains that the 'authoritative discourse' model represents an especially useful analytical framework for evaluating the impact of ideological language in the context of the Communist system. the model both helps to explain the relative acquiescence of most of the population, and also to track the extent to which the 'coded' message of the approved discourse was successful in slowing the demise of the regime.

\section{Introduction}

This article employs a combination of historiography and discourse analysis to contextualize and evaluate official reflections on the Prague Spring, and their impact on policy and language, in the last two years of Communist rule in Czechoslovakia. The study begins by setting the diachronic parameters of the debate, and by addressing the question of the decline of the symbolic authority of the Party's rhetoric. The main body of the article then presents a detailed frequency-based lexicological investigation into the argument employed in selected texts in reassessing the ideological 'lessons' of the late 1960s. The texts consulted were all published in the mass-circulation Czechoslovak Communist Party daily, Rudé právo, and date largely from 1988, in response to the twentieth anniversary of the Warsaw Pact intervention (20-21 August 1968). ${ }^{1}$ Most of the pieces cited also appear in a little-known volume, Nezažloutlé stránky roku 1968 (The Unfaded Pages of 1968), which (in a slightly expurgated form) provides the corpus for the lexical and thematic discussion (hereafter, Legacy Corpus). ${ }^{2}$

The study's principal contribution to knowledge resides in its in-depth language analysis. An empirical lexicological approach of the type adopted here

\footnotetext{
${ }^{1}$ The importance of Rudé právo as (effectively) the mouthpiece of the Central Committee can barely be overstated. It enjoyed much larger print-runs than all other daily papers, and it reached a readership well beyond Party members and Communist sympathizers According to Zdeněk Hoření, editor-in-chief from 1983 to 1989, sales peaked at 1,200,000 copies (1,600,000 on Saturdays). See Miroslav Vaněk and Pavel Urbášek, Vitězové? Poražení? Životopisná interview 2 (Prague, 2005): 138-71 (156).

${ }^{2}$ Nezažloutlé stránky roku 1968, ed. by Jana Perglerová (Brno, 1989) (hereafter NS). This was the penultimate in a series of propaganda works published by Knihovna Rudého práva, and consists of a foreword by Hoření, and a series of fifty-two articles, editorials, speeches, conversations, and readers' letters, dating from October 1987 to April 1989, and clustered around four themes: events, opponents, readers' memories, and recent developments. Six pieces reprinted in Nezažloutlé stránky are omitted from the corpus: three not originally published in Rudé právo - Hoření's introductory comments, 'Slovo úvodem'; an article by an unnamed author, 'K výročí čs. krizových událostí', 12 July 1988 (NS, 180-81), which first appeared in Polish in the monthly Zdanie; a bombastic piece by the hardline Central Committee member, Jan Fojtík, 'Pevným a rozhodným krokem vpřed', published in the newspaper Hospodárské noviny, January 1989 (NS, 184-90); and three which barely relate to the theme of the Prague Spring - Zdeněk Hába’s article on economic reform, 'Vlny nestejné výšky’, 23 June 1988 (NS, 191-98); a conversation with Jiří Kohout, 'Kam směřovaly “demokratizační koncepce” v roce 1968: Socialismus, demokracie, občan', 21 January 1988 (NS, 199-202); and a series of answers by the First Secretary of the Communist Party, Miloš Jakeš, to questions posed by Hoření, 'Nové podněty naší iniciativy', 25 February 1989 (NS, 213-19). Also omitted from the corpus is the list of contents. All the original headings and sub-headings are, however, included. The edited corpus is 65,826 words long.
} 
offers three particular advantages: (1) it helps to overcome any preconceptions and misconceptions inherent in existing historical accounts; (2) it reduces possible bias emanating from the researcher's own positionality; and (3) it provides statistical evidence to indicate continuity or change in the officially approved paradigm, however marginal the latter may prove to be. A careful reading of the texts, supported by corpus-informed frequency data, affords the researcher a more objective basis for reaching conclusions about the interpretation of the experiences of the past. It allows the investigator to confirm the expected, whilst simultaneously subverting intuition and drawing attention to the less readily discernible. Specifically, in the current context, it serves to highlight the turgidity and sterility of the official word, whilst also identifying a number of minor changes in the use of vocabulary and phraseology, and other subtle deviations from the established norms, especially in terms of tone and style.

There has thus far been relatively little serious scholarship on the political rhetoric of the final years of Czechoslovak Communism. ${ }^{3}$ This is perhaps unsurprising in view of the Party's strict adherence to the conventions of socialist myth-making and pro-Soviet propaganda. However, for all the predictability of the officially sanctioned sophistry, it cannot be dismissed merely as a seamless continuation of the pre-Gorbachev era. The very nature of its defining discourse theme - the events of 1968 - required its promulgators to engage, at least at a superficial level, with more problematic questions which had hitherto been confined to the private domain. Whereas the contributors to Rudé právo had previously been able to promote a narrowly prescribed linear narrative, they now had to partake in the much more complex process of managing expectations and countering alternative perspectives. What makes the documents of the late 1980s so intriguing is precisely their attempt to adhere to a moribund political credo which no longer made much sense in view of the reforms being introduced in Moscow.

Party stalwarts were faced with the invidious task of reconciling Gorbachev's policy of perestroika (known in Czech by the loan translation prestavba) and, to some extent, glasnost (although the latter was never officially proclaimed in Czechoslovakia) with their commitment to their orthodox interpretation of the Dubček era. Their inflexible and immutable evaluation of the Prague Spring is enshrined in the seminal work, Poučeni z krizového vývoje ve straně a společnosti po XIII. sjezdu KSČ (Lessons Drawn from the Crisis Development in the Party and Society after the 13th Congress of the Communist Party of Czechoslovakia [31 May-4 June 1966]), which originally appeared as a sixteen-

\footnotetext{
${ }^{3}$ A notable exception is Michal Pullmann, Konec experimentu: Přestavba a pád komunismu v Československu (Prague, 2011). Pullmann looks at the function of language in the late 1980s within the context of the authority of ideology, especially in the economic sphere, but does not use corpus-informed methods.
} 
page supplement to Rudé právo on 14 January $1971 .{ }^{4}$ Poučení was a hugely influential publication. Not only did it play a major role in determining the ideological scope of Normalization (later generally referred to as 'consolidation'), but it also provided the semantic, conceptual, and stylistic framework for all forms of public engagement during this period. ${ }^{5}$ Even in the late 1980s, it was the principal referent for the conservative politicians who held sway in the Central Committee of the KSČ, and it was a thorn in the side of more reform-minded Communists, such as Lubomír Štrougal (Prime Minister of Czechoslovakia, 1970-88). ${ }^{6}$ As long as the legitimacy of Poučeni could be asserted, it remained a potent symbol of the old order.

\section{Historical context}

The late 1980s in Czechoslovakia, as in most of the Communist world, was a time of significant reflection and debate within Party circles and the public at large, in response to the initiatives in the USSR, industrial slowdown, the need for modernization, environmental matters, and numerous social problems. In order to contextualize the pieces cited in this study, it is therefore necessary to have a detailed overview of political and economic developments. ${ }^{7}$ The starting point of prestavba was arguably the acceptance of the principle of restructuring by the Presidium of the Central Committee on 17 December $1986 .{ }^{8}$ A more direct impulse for transformation were the deliberations of the plenary session of the Central Committee of the Communist Party of the Soviet Union (CPSU) on 2728 January 1987, which were published in full in Rudé právo. ${ }^{9}$ According to Štefek, their dissemination was greeted enthusiastically by Štrougal, but Vasil Bil'ak (Secretary of the Central Committee of the KSC, and chief ideologist, 1968-88) was at pains to stress the continuing validity of Poučeni ${ }^{10}$ Reforms were then discussed in earnest at the twenty-seventh meeting of the Presidium of the Central Committee on 18 February (continued on 26 February). Again opinions were divided, with broad acceptance of the need for economic and political change, but with Bil'ak and others stressing the specifics of the

\footnotetext{
${ }^{4}$ Poučení z krizového vývoje ve straně a společnosti po XIII. sjezdu KSČ (Prague, 1971) (hereafter Poučeni). The text was published in numerous editions in Czech, Slovak, and other languages up to 1988. For the purpose of statistical diachronic comparison, reference is made to a corpus of keywords and collocations employed in an earlier analysis of the language of Poučeni. See Tom Dickins, 'The Impact Factor of the Language of Czechoslovak Normalization: A Study of the Seminal Work Poučení z krizového vývoje ve straně a společnosti po XIII. sjezdu KSČ', Slavonic and East European Review 93 (2015): 213-50.

5 The forms konsolidacelkonsolidační (consolidation) are cited 23 times in Legacy Corpus, whereas normalizace occurs just once.

${ }^{6}$ Although Štrougal was one of the Party's most important 'normalizers', he had openly advocated new thinking since 1985. See 'Významný dokument našich novodobých dějin. Projev soudruha Lubomíra Štrougala na shromáždění v Košicích', Rudé právo, 5 April 1985, 2-3.

${ }^{7}$ For an accessible and succinct summary of the most significant changes, see Martin Štefek, 'Proces přestavby a proměny nedemokratického režimu v ČSSR', Člověk (8 June 2012), accessed 30 June 2014, http://clovek.ff.cuni. cz/rservice.php?akce=tisk\&cisloclanku=2015060802\#_ftn33.

${ }^{8}$ Národní archiv, fond 02/1 - předsednictvo ÚVKSČ, a. j. 23, b. 3, Př́iloha I. See Martin Štefek, 'Proces přestavby'.

9 'O přestavbě a kádrové politice', Rudé právo, 28 January 1987, 1 and 3-6; 29 January 1987, 1 and 6; 30 January $1987,7$.

${ }^{10}$ Národní archiv, fond 02/1 - předsednictvo ÚVKSČ, a. j. 26/87, b. 1, Př́loha I. See Štefek, 'Proces přestavby'. Bil'ak was almost certainly in charge of the team of hardline Communists who wrote Poučení.
} 
Czechoslovak situation. ${ }^{11}$ On 3 March 1987, Štrougal sought to push a more progressive agenda, with a speech at the Lucerna Palace, but he failed to receive widespread support from other Central Committee members for his proposed reforms. ${ }^{12}$ Gorbachev's visit to Czechoslovakia on 9-11 April 1987 changed little, with the Soviet leader careful to avoid polemical matters, such as the Prague Spring. ${ }^{13}$ Much of the remainder of 1987 was devoted to discussing the implementation of the changes agreed in February. At the seventh plenum of the Central Committee in December 1987, 'conservatives' won the debate over the separation of the functions of President and General Secretary, with the result that Miloš Jakeš (a compromise candidate, with orthodox instincts) replaced Gustáv Husák as Party leader. The KSČ also adopted a resolution guaranteeing economic restructuring, together with a new plan up to 1990, but there was little enthusiasm for real democratization or greater civil liberties. ${ }^{14}$ Indeed, a peaceful candle-lit demonstration in Bratislava on 25 March 1988 by Catholics demanding more rights for believers was forcefully dispersed, and resulted in around a hundred arrests. The ninth session of the Central Committee on 8-9 April 1988 confirmed the victory of the pro-Jakeš majority, and heralded, inter alia, the introduction of younger blood into the Party hierarchy. ${ }^{15}$ Yet, such was the entrenched position of the leadership that even the announcement of greater liberalization at the nineteenth All-Union Conference of the Central Committee of the CPSU, in Moscow from 28 June to 1 July, prompted little official response.

The rest of the Communist era was characterized at a political level by a series of cautious reactions to events largely outside the Party's control. Change in 1989 happened at a slower pace in Czechoslovakia than in some of the other Soviet satellite states. In Poland, the Round Table Agreement between the Communists and the opposition in April ensured partly free elections, and in Hungary, in May, the authorities started to dismantle its border fence with Austria, with the result that East German citizens fled through Hungary to the West, via Czechoslovakia. ${ }^{16}$ Even in Czechoslovakia, however, people became aware of the new opportunities for dissent, and increasingly expressed their discontent. A number of protests took place in 1989, prior to the Velvet Revolution, which symbolically weakened the authority of the regime and emboldened its opponents. These included several days in January, to commemorate Jan Palach (who committed suicide in 1969 in protest against the Soviet-led intervention); in August, to recall the occupation; and in October, to mark the anniversary of

\footnotetext{
${ }^{11}$ Národní archiv, fond 02/1 - předsednictvo ÚVKSČ, a. j. 28/87, b. 13. See Štefek, 'Proces přestavby'.

12 (es, nn), 'Rozhodujícím měřítkem jsou výsledky hospodaření', Rudé právo, 3 March 1987, 1.

${ }^{13}$ See, for example, Hans Renner, A History of Czechoslovakia since 1945 (New York, 1989), 160.

14 'Usnesení ÚV KSČ o komplexní přestavbě hospodářského mechanismu ČSSR a jejím zabezpečení. See 'Důvodová zpráva $\mathrm{k}$ návrhu zákona o státním podniku', FS ČSSR, 1986-1990, accessed 22 July 2014, http://www.psp.cz/ eknih/1986 fs/tisky/t0064_04.htm.

${ }^{15}$ By the end of 1988 , both Štrougal and Bil'ak had been removed from office.

${ }^{16}$ By the time the border crossing between Czechoslovakia and East Germany was closed on 3 October 1989, the movement for change in East Germany was irresistible.
} 
the foundation of the Czechoslovak state. Opposition groups, such as České děti (Czech children), Český svaz ochránců př́rody (Czech Union of the Protectors of Nature), Demokratická iniciativa (Democratic Initiative), Hnutí za občanskou svobodu (Movement for Civic Freedom), Klub 'Obroda' ('Revival' Club), Nezávislé mírové sdružení (Independent Peace Association), and Společnost prátel USA (Society of Friends of the USA), began to make their voices heard. Underground music and literature, including the samizdat newspaper Lidové noviny, likewise reached a slightly wider audience. ${ }^{17}$ By late 1989, 600,000 Czechs and Slovaks had signed a petition for greater religious freedom, supported by Cardinal Tomášek, Archbishop of Prague, and around 47,000 people had signed the Charter 77 petition for political rights, Několik vět (A Few Sentences), launched on 29 June. The government could no longer simply ignore the concerns of ordinary citizens and world opinion, so it sought to manage them through a combination of selective repression, campaigns of misinformation, further concessions, and conciliatory gestures (such as the early release of Václav Havel from prison in May 1989). ${ }^{18}$

Ironically, perhaps the event that made the greatest impact on the public, in terms of undermining the authority of the Party and official discourse, was a speech by its most prominent representative, Miloš Jakeš, in Červený Hrádek in July 1989 - a recording of which was leaked, copied, and illicitly circulated throughout the country. ${ }^{19}$ His address to regional Party dignitaries, which was inarticulate, inappropriately colloquial, and inadvertently humorous, exposed the First Secretary and, by extension, the Party itself, to ridicule. Amongst other things, Jakeš appealed for support from below to avoid being left all alone, jak kủl v ploté (literally 'like a stake in the fence'), he confused the nouns brojler (broiler) and bojler (boiler), he criticized performers, such as the pop singer Hana Zagarová and the rock star Petr Janda, for their inflated earnings, and, most surprisingly, he compared the obsolete state of the Soviet Union with the high level of culture and sophisticated household equipment in Czechoslovakia. Had Jakeš read from a carefully prepared script and stuck to the clichés and shibboleths with which he was so familiar, his contribution would doubtless have been forgotten, like most of his other public appearances. The fact that he chose, and failed embarrassingly, to engage with the issues of the day, highlighted both his intellectual limitations and his poor grasp on reality.

It is against the backdrop of the aforementioned developments, especially in 1988, that the texts chosen for analysis here have to be seen. The discourse

\footnotetext{
${ }^{17}$ Lidové noviny, which first reappeared in September 1987, offered a fascinating contrast to Rudé právo (accessed 24 March 2016 , http://www.lidovky.cz/historie-obrazem.aspx?datum=1987_09).

${ }^{18}$ For an illustration of the range of topics in the public domain and the official response to them, see, for example, Jiři Kohout, ed., Čtenár má právo védět (Brno, 1989) - the last of the series of propaganda works published by Knihovna Rudého práva (referred to in n. 2). This short volume considers themes as diverse as economic reform, foreign trade, tourism and travel, expressions of protest, the environment, European safety and cooperation, disarmament initiatives, religion, historical agreements and new technology.

${ }^{19}$ The speech is available at http://www.youtube.com/watch?v=uTaTJOAzb0 g. Accessed 8 September 2014.
} 
reflects the unsatisfactory nature of the political compromise, in which the Party leadership officially advocated reform, especially in the economic sphere, but categorically rejected the notion of a renewal process (obrodny proces) akin to that of the late 1960s. ${ }^{20}$ The left of the Party was particularly wary of any developments that might further undermine Soviet authority or lead to parallels with or suggest the validity of the Prague Spring. As late as April 1989, when Jakeš met Gorbachev in Moscow, his main request was that the official representation of history, especially 1968 , be respected. ${ }^{21}$ Gorbachev agreed, although privately he acknowledged the military operation to be a mistake, ${ }^{22}$ and he knew that the system could no longer control the content and style of debate in the way that it had in the past. So out of touch with reality was the KSČ that, even as the regime was in its death throes on 18 November 1989, Rudé právo ran with a lead story celebrating the Month of Czechoslovak-Soviet Friendship. ${ }^{23}$ The failure of the Party leadership to recognize the public mood is even more graphically illustrated in the transcript of two extraordinary Central Committee meetings on 24 and 26 November 1989, in which senior Communists continued to deny their imminent demise. ${ }^{24}$

\section{Decline of the authority of Party propaganda}

This study broadly endorses the 'authoritative discourse' model, outlined by Alexei Yurchak and developed by Michal Pullmann, which is based on Bakhtin's concept of the existence of hierarchically superior 'texts'. ${ }^{25}$ Canonical discourse, in Bakhtin's schema, depends for its unconditional acceptance on the authority that it has acquired over time, and in relation to developments in society. Pullmann opposes the notion of a binary opposition between 'good' (as exemplified by the silent majority) and 'bad' (as represented by the Party), and, instead, focuses on the role of linguistic and cultural ritual in both the creation of a fragile social consensus and the subsequent collapse of the regime. He essentially argues that, as long as ideological language is underpinned by unambiguous and unchallengeable policies, it will serve to reinforce the symbolic order, thereby minimizing the scope for subversive forms of metadiscourse. According to Pullmann, the endless repetition of hypernormalized, ideologically empty phrases after 1970 helped to establish a degree of social reconciliation, in which conflict and violence were rendered

\footnotetext{
${ }^{20}$ The specialist economic body, the Institute for Forecasting, Prognostický ústav (originally Kabinet prognóz ČSAV), 1984-92, was considerably less constrained by narrow Party ideology than most other organizations, especially after December 1986.

${ }^{21}$ See Pullmann, Konec experimentu, 202.

${ }^{22}$ See Mikhail Gorbachev and Zdeněk Mlynáŕ, Conversations with Gorbachev: On Perestroika, the Prague Spring, and the Crossroads of Socialism, trans. George Shriver (Columbia, 2003), 6.

${ }^{23}$ Unnamed eds, 'Přátelství pevné, hluboké', Rudé právo, 18 November 1989, 1.

${ }^{24}$ Marianna Krtilová, ed., Posledni hurá: Stenografický záznam z mimořádných zasedání ÚV KSČ 24. a 26.11. 1989 (Prague, 1992).

${ }^{25}$ Alexei Yurchak, Everything Was Forever, Until It Was No More (Princeton, 2005); Pullmann, Konec experimentu; and Mikhail Bakhtin, The Dialogic Imagination: Four Essays, ed. Michael Holquist, trans. Carol Emerson and Michael Holquist (Austin, TX, 1982).
} 
largely invisible. The so-called decent citizens (poctiví občané), much-vaunted in Party rhetoric, were prepared to suppress their misapprehensions in the name of a mythical socialist utopia. This afforded them a quiet life, and allowed them to pursue their careers and leisure-time activities without the threat of disturbance, as reflected in the slogan klid na práci (the opportunity to work in peace). People were not required to believe the official propaganda; they merely had to take heed of its 'coded' message. Pullmann's somewhat unorthodox analytical approach which, in common with oral history, accentuates the subjective nature of human perceptions, has been termed the 'revisionist paradigm' by Jakub Rákosník. ${ }^{26}$ While it may understate the widespread dislike of the regime, it goes a long way to explaining why so many people resigned themselves to the system, and it perhaps accounts for a degree of nostalgia today for the certainties (if not the abuses) of the past. It also implicitly counters the glib assumption that everything was equally unpalatable and oppressive under normalization.

In Pullmann's conceptualization of Czechoslovak Communism, concerted opposition remained well-nigh impossible as long as the majority of the population continued to pay lip-service to the established norms, and organized their lives around those norms. Social constructionists would point to the existence of a coordinated understanding and view of the world, based on shared experiences and knowledge, mediated through language. ${ }^{27}$ At one level, Czechs and Slovaks rejected the construction of reality foisted upon them by a ruling elite which they held in very low esteem; yet, on another, they accepted it as a fait accompli, to which they had to acquiesce. In the terms of framing theory, the Party organized and defined official reality, while people created their own parallel reality, which limited their engagement with the imposed system. ${ }^{28}$ As Pullmann has observed, authoritative language allowed for a relatively wide range of attitudes and practices in everyday life which did not necessarily have anything to do with socialism. ${ }^{29}$ Most people preferred to make the best of a very unsatisfactory situation and enjoy the limited benefits of socialist consumerism rather than engaging in a struggle against the status quo, which was neither in their short-term self-interest nor to the immediate advantage of their family. They learnt to differentiate from an early age between official representations of the

\footnotetext{
${ }^{26}$ Jakub Rákosník, 'Tř́i cesty soudobé české historiografie komunismu', in Český a slovenský komunismus (1921-2011), ed. Jan Kalous and Jiř́ Kocian (Prague, 2012), 13-23. Rákosník contrasts the 'revisionist paradigm' both with the predominant 'totalitarian paradigm', which highlights the repressive policies of the all-powerful regime, and the 'modernization paradigm', which seeks to draw parallels with developments in advanced Western societies.

${ }^{27}$ See, for example, Vivien Burr, An Introduction to Social Constructionism (London, 1995).

${ }^{28}$ See Erving Goffman, Frame Analysis: An Essay on the Organization of the Experience (New York, 1974).

${ }^{29}$ Pullman, Konec experimentu, 92.
} 
'truth' and their private experiences, and made the appropriate adjustments to the way they spoke and what they said, depending on the audience. ${ }^{30}$

Not all citizens, however, were prepared to occupy what has been called the 'grey zone' (šedá zóna) between compliance and opposition, or indifference and hostility. ${ }^{31}$ A significant number actively supported Normalization, either through conviction or expediency, while others, such as Václav Havel, had the courage to reject it publicly. ${ }^{32}$ In his famous letter to Husák, Havel pointed out that "internally our society is not only not at all "consolidated", but is subsiding into an ever greater crisis', and he attributed the 'imposing impression of a totally unified society, totally supporting its government' to fear alone. ${ }^{33}$ Although Havel's voice was not widely heard outside opposition circles before 1989, many would have subsequently identified with his fictional greengrocer, who prostrates himself before the regime, in which he does not believe, by displaying the sign Proletáři všech zemí, spojte se! (Workers of the world, unite!). ${ }^{34}$ The parallels with shouting carefully orchestrated slogans at May Day parades, or using the greeting Čest práci, soudruhu! (Glory to work, comrade!), or flying the Soviet flag alongside the Czechoslovak flag outside apartment windows were only too obvious to those who later read Havel's work.

It was not until the official codification began to break down in the late 1980s, and apprehension gradually gave way to aspiration, that people started to express their true feelings about the system. As the Prague Spring had already proven, once the Party loses control of events and the prestige of the authoritative discourse is damaged, it sets in motion a process of transformation which is difficult to control. By 1988, endorsed concessions lagged behind public demands. Such was the desire for substantive reform, especially amongst the young, that changes made by the Party, which would previously have been greeted with enthusiasm, now seemed inadequate. Examples included the easing of restrictions on foreign travel, the symbolic reintroduction of 28 October (the anniversary of the foundation of Czechoslovakia) as a public holiday, the unjamming of foreign radio stations, the authorization of an opposition Human Rights Day demonstration on 10 December (later declared illegal), and the preparation of a new constitution. The concepts of prestavba, cited 104 times, or 158 parts per million (henceforth, ppm), and demokratizaceldemokratizační (democratization), cited 18 times, or 27 ppm, in Legacy Corpus, increasingly permeated formal political discourse, but they did not greatly inform ideology. It

\footnotetext{
${ }^{30}$ Note, for instance, in children's speech, the contrast between the official form of address, soudružko učitelko (comrade teacher) the contraction souška učitelka, sometimes adopted ironically by the adult generation, and the privately used form pani učitelka (Mrs Teacher).

${ }^{31}$ See Jiřina Šiklová, 'The "Gray Zone” and the Future of Dissent in Czechoslovakia', Social Research 57 (1990): $347-65$.

${ }^{32}$ In 1989, membership and candidate membership of the KSČ stood at around 1,725,000, out of a total population (including children) of about $15,600,000$.

33 Václav Havel, Dopis Gustávu Husákovi, 8 April 1975, accessed 30 June 2014, http://www.vaclavhavel.cz/showtrans. php?cat=clanky\&val=71_clanky.html\&typ=HTML.

34 Václav Havel, Moc bezmocných (Prague, 1990).
} 
is difficult to evaluate the statistical significance of these lemmas, in the absence of data from other comparable synchronic corpora, but the former, at least, is much more common towards the end of the 1980s than in the pre- and postGorbachev lexicon. In the ten-million word corpus comprising Slovník komunistické totality (Dictionary of Communist Totalitarianism) (hereafter, SKT), which compares texts from 1952, 1969, and 1977, prestavba occurs a total of 904 times (70 ppm), and in the 100-million corpus-based Frekvenčni slovník češtiny (Frequency Dictionary of Czech), based mainly on texts from the 1990s, it is cited 1956 times (roughly $20 \mathrm{ppm}$ ). ${ }^{35}$ The failure of the Party to match its reformist rhetoric with radical action engendered opposition in fields as diverse as popular culture, life-style choices, the environment, and religious belief. In the workplace, however, greater caution prevailed, and officially promoted changes sometimes met with resistance. Pullmann has pointed out that managers of enterprises welcomed greater self-determination, but criticized the principle of worker self-rule for fear of losing their authority. Party functionaries, especially at regional level, also opposed some of the initiatives. Workers were often equally unenthusiastic, since the proposals were announced from above, and potentially threatened job security and conditions of employment. ${ }^{36}$

By the end of the 1980s, the Party had not only lost much of its credibility, but also its raison d'être. Once the Soviet authorities had come clean about the crimes of the past, especially Stalinism, and had abandoned the Brezhnev Doctrine (which subordinated national sovereignty to proletarian internationalism, as articulated in Pravda on 26 September 1968), there was no longer any need for Czechoslovakia to stick to the old structures. ${ }^{37}$ Yet, for advocates of Normalization, there was also no alternative. If any doubts about 1968 and the Warsaw Pact intervention existed, Poučeni $i$ and the leading role of the Party would be rendered untenable, and the fallacy of the specificity of the Czechoslovak situation would be exposed. The logical inference of glasnost for ideologues was that the very source of their authority - the Kremlin - had deviated from Marxism-Leninism, but this was an unthinkable proposition, which would undermine the basis of their geopolitical alliance. As Komenda, a senior Party member in České Budějovice, has remarked, Communists at a regional level noted with interest that the Soviet Union, which had always been their role model, was no longer regarded as such. ${ }^{38}$ In the absence of an externally imposed ideology, there was little to legitimize their authority - the

\footnotetext{
${ }^{35}$ See Slovník komunistické totality, ed. František Čermák, Václav Cvrček, and Věra Schmiedtová (Prague, 2010); and František Čermák, Michal Křen, et al., Frekvenčni slovník češtiny (Prague, 2004).

${ }^{36}$ Pullman, Konec experimentu, 87-92.

${ }^{37}$ See S. Kovalev, 'Sovereignty and the International Obligations of Socialist Countries', in Winter in Prague. Documents on Czechoslovak Communism in Crisis, ed. Robin Alison Remington (Cambridge, MA, 1969), 413-16.

${ }^{38}$ Vaněk and Urbášek, Vitězové? Poraženi? , 318-71 (p. 347).
} 
Party could not even appeal to traditional Russophilism or Slavophilism or to post-war pro-Soviet sentiment.

\section{Analysis of the texts}

This contribution to the study of late Communism attempts to answer three interrelated questions:

(1) What do the texts from Rudé právo tell us about the significance of Poučeni as a reference point in the history of Normalization?

(2) To what extent do the argument and language employed in the selected texts indicate a departure from or a reaffirmation of the norms of the preGorbachev era, as reflected in Poučeni and SKT?

(3) How do the pieces in Rudé právo seek to construct a 'new' reality, in the light of the changes in the Soviet Union and other Warsaw Pact countries, and what are the implications of their attempts to do so?

In order to address these questions, a corpus-informed lexicological approach is adopted. The use of statistical data enables the researcher to focus on shifts in vocabulary and phraseology, while at the same time drawing attention to more subtle changes in the nuances and tenor of the debate. The corpus does not claim to be representative of all the official discourse of the time, or even of all the overtly political official discourse of the time - which would be a huge and problematic undertaking, given the heavily politicized nature of most forms of public debate - but it is indicative of a defining sub-group of texts, which sought to interpret prestavba in terms of the ideological lessons of the past. Political discourse might seem an unusual theme to choose for detailed linguistic investigation, given that this is the area of language least susceptible to variation in a Communist state. But it is precisely the fact that political rhetoric is so fossilized that makes it such an important barometer of the conditions of the 'socio-cultural' atmosphere of the time. Any suggestion of a departure from the past in the representation of official ideology is indicative of more significant developments in society, and has a potential impact on the authority of the Party.

The overall conceptual and stylistic framework of the contributions to Rudé právo is set by Jakeš's speech in celebration of the fortieth anniversary of 'Victorious February' (the foundation of the Communist state in 1948). ${ }^{39}$ It is poorly structured, wooden, and doctrinaire. Jakeš blames the economic problems of the 1960s largely on two phenomena: subjectivism and voluntaryism (voluntarismus) - concepts widely used in official circles, but probably inaccessible to much of his audience. He criticizes the lack of changes in the methods adopted by the Party, the state organs and the cadres for their failure to implement the necessary solutions, as well as a decline in 'the Party's ability to act, and its ideological unity and connection with the people' (akceschopnost

39 'Z projevu soudruha Miloše Jakeše na slavnostním zasedání ke 40. výročí vítězného února', 25 February 1988 (NS, 6-7). 
strany, její ideová jednota a spojení s lidem). He also appeals to people's ignorance to reaffirm the sole legitimacy of the interpretation of the past presented in Poučeni: 'It contains the true view of the events of the time, and even today there is no reason to change it. ${ }^{40}$ The importance of drawing the 'correct' conclusions from the past is reinforced by the 61 citations in Legacy Corpus of P/poučenilpoučováni (enlightenment, lessons learnt) and the 5 occurrences of poučit se (to draw a lesson) - a combined total of roughly 100 ppm. Jakeš seeks to dispel any suggestion that the developments in Czechoslovakia in 1968 might be a precursor to prestavba by distinguishing between the 'revolutionary bequeathal' (revolučni odkaz) of October 1917 and February 1948, and the reform Communists' attempts to annul the achievements of socialism. He also reiterates the well-worn argument that international assistance' (internacionální pomoc) - a phrase used 14 times in Legacy Corpus - averted a tragedy. His contribution is replete with the hackneyed expressions of Normalization speak: antisocialistické elementy (anti-socialist elements), konsolidačni proces (consolidation process), krize ve straně a společnosti (crisis in the Party and society), reakční kruhy (reactionary circles), Vitězný únor (Victorious February), zdravé síly (healthy forces), and others. The terms antisocialistický/protisocialistický (anti-socialist) and antisocialismus (antisocialism), are cited 75 times, 114 ppm, in Legacy Corpus, compared with 264 ppm in Poučení; krizelkrizový (crisis) and predkrizový occur 104 times, 158 ppm, compared with $881 \mathrm{ppm}$ in Poučení; and Únor/únor/únorový (February), and its derivatives antiúnor (anti-February), predúnorový (pre-February) and poúnorový (post-February) are found 96 times, 146 ppm, compared with 107 ppm. The absence of any substantive criticism of the abuses of Stalinism or of the inflexibility of Communist ideology testifies to the orthodoxy of his vision.

Jakeš employs all the formal economic rhetoric of the period, including buzzwords such as intenzifikace (intensification) and urychlení (acceleration), but avoids allusion to meaningful political change. On the contrary, he implicitly advocates strengthening the leading role of the Party:

The reaction to the new situation, which demanded a consistent changeover to intensification, to acceleration in scientific and technical development, and to the implementation of new methods of management, was slow. Complacency manifested itself in many places in the sphere of management, the solution to problems was postponed, and Party and state discipline, as well as their operational control, were weakened. ${ }^{41}$

The noun intenzifikace, which emphasizes effective 'intensive' exploitation of resources, has no citations per million in SKT for 1952, compared with 8 in

\footnotetext{
40 'Z projevu soudruha Miloše Jakeše', 6: 'Je v něm obsažen pravdivý pohled na tehdejší události a ani dnes není důvodu jej měnit'

41 'Z projevu soudruha Miloše Jakeše', 6: 'Reakce na novou situaci, která vyžadovala důsledný obrat k intenzifikaci, k urychlení vědeckotechnického rozvoje, k prosazení nových metod řízení, byla pomalá. Na mnoha místech v řídící sféře se projevovalo sebeuspokojení, řešení problémů se odkládalo, oslabovala se stranická a státní disciplína i kontrolní činnost'.
} 
1969, and 45 in 1977. By contrast, the figures for urychleni are 52, 14, and 44 ppm, respectively. In Legacy Corpus, which excludes specifically economic texts, intenzivní (intensive) and its cognates intenzifikace and intenzifikační ('intensificational') occur 10 times (roughly $15 \mathrm{ppm}$ ), while urychlení, urychlený (accelerated), and urychleně [adverb] are cited 13 times (approximately $20 \mathrm{ppm}$ ). The nearest that Jakeš comes to recognizing the seriousness of the situation is his acknowledgement of the Party's failure to respond adequately to the international economic crisis at the end of the 1970s and the start of the 1980s. This is noteworthy, since it implicitly distances him from the policies of the former leadership, but it completely ignores shortcomings inherent in the structure of the command economy.

The difficulty for the Communist hierarchy was that economic decline was a corollary of political failure. By 1988, the Party elite spoke to and for an increasingly small minority, and used a language that no longer carried either conviction or weight. Propaganda as a 'speech act' had lost much of its perlocutionary force, ${ }^{42}$ and most people had abandoned any hope that the system could be reformed from within. The fragile consensus had been broken, as encapsulated in slogans such as Máme toho dost (We've had enough) and Kdo, $k d y z ̌$ ne my, kdy, když ne ted!! (Who, if not us; when, if not now!), employed in the Velvet Revolution in November 1989. The political discourse of the late 1980 s is distinguished from that of the early 1980s not by its greater objectivity or openness, but merely by the illusion that it creates of more meaningful engagement, especially through its reference to a wider range of detail and sources, and through the emergence of different types of public forum. This is clearly illustrated by the Rudé právo round table 'discussion' of the events of 1968 in August 1988, in which nine establishment figures (all men) virtually vie with each other to demonstrate their loyalty to the official interpretation of the regime.$^{43}$ Were the context of the discourse not so portentous and the content so unchallengeable, the exchanges would have something of the humorous hyperbole of the Monty Python's Flying Circus 'Four Yorkshiremen' sketch.

The debate identifies many of the usual themes of Normalization: the necessity of January $1968 ;{ }^{44}$ the role of right-wing opportunists in the Prague Spring; the weakness of the Dubček leadership; the passivity of the working classes; the divisive activities of the West; the emergence of opposition groups, such as K 231 (the Club of Former Political Prisoners) and KAN (the Club of the Non-Party Activists); the infiltration of Svaz mládeže (the Union of Youth) and the trade union movement; the erosion of the authority of the security forces; the

\footnotetext{
${ }^{42}$ For more on the concept of perlocution, see J. L. Austin, How to do Things with Words (Oxford, 1962).

${ }^{43}$ František Černohorský and Jiř́ Kohout, 'Kulatý stůl Rudého práva a pravdy o roku 1968: O lidech a událostech', 11 and 12 August 1988 (NS, 8-19).

${ }^{44}$ After a long struggle, an alliance of senior Party members forced Antonín Novotný (General Secretary of the KSČ from 1953, and President of Czechoslovakia from 1957) to quit as Party leader and subsequently as President.
} 
breakdown of order; the atmosphere of physical and moral terror; the threat of violent conflict; the attempts to turn Czechoslovakia into a neutral state, based on the pre-Munich model; the Party's Akčni program (Action Programme), published on 5 April 1968; Ludvík Vaculík's 'counter-revolutionary' (reformist) manifesto, 2000 slov (The Two Thousand Words), published on 17 June 1968; Ota Šik's economic policies, and so on. Yet, where the content deviates from that of the established canon is in the wide range of supplementary details that it provides, which would previously have been confined to a small clique. Examples include the role of Emil Vydra, former head of K 231, who later 'fled' (utekl) to the West; the 'adventurism' of Ivan Sviták, one of the leaders of KAN, also 'active in emigration' (puisobi v emigraci); the publication of the so-called (Czech) Black Book (Černá kniha), which presents eyewitness accounts of and other documentation on the Warsaw Pact intervention; and an article written by Havel in April 1968 in the journal Literární listy. ${ }^{45}$ The references to materials largely inaccessible to ordinary Czechs and Slovaks in 1988 unwittingly invited further speculation about the nature of the control and dissemination of information, as considered in more detail later.

As soon as the round table panel switches from the certainties of the past to the dilemmas posed by prestavba, the discourse becomes more dependent on Communist dogma and more abstract, as evidenced by opaque nouns such as formalismus (formalism) and existencionalismus (existentialism). It begins with the assertion that people are in favour of prestavba, and that the majority want to effect it. It then identifies the need for a strong united Party, at one with the people, based on the Leninist conception of the vanguard of society and in keeping with the traditions of Bolshevism. It counsels against the misuse of prestavba and comparisons with 1968, and argues that restructuring should serve to strengthen socialism, rather than lead to its demise. The validity of Poučení is reaffirmed, with the document being interpreted as a route map for future development, and with the current problems attributed to inadequate resolution of the issues it identifies. Medved' stresses that if the Party had stuck to Leninist principles and norms, the crisis of 1968 would have been avoided, and people would not have had to pay a high price for their mistakes. In other words, the system itself is immune from substantive criticism, and all reforms have to be based on the ossified ideology and policies of the past. For all except the most devoted of Communists, the message was one of despair, but for the conservative wing of the Party any other approach would have been tantamount to relinquishing power.

\footnotetext{
${ }^{45}$ Emigration was perceived negatively by the Czechoslovak authorities (and by much of the population), even though leading dissidents were strongly encouraged to leave Czechoslovakia. The actual title of the Black Book (so named because of its 'dark' content, as reflected in the colour of its cover) is Sedm pražských dnů. 21.-27. srpen 1968: Dokumentace (Prague, 1968). The article referred to is Václav Havel, ‘Opozice v Literárních listech', Literární listy 6.4 (1968): 4.
} 
The language of the round table is largely predictable and clichéd. It contains the standard devices of political rhetoric, such as repetition to emphasize a point, the use of reflexive verbs and the passive voice to avoid reference to specific agency, and stylized nominalization to impart a degree of formality and gravitas to the subject matter. An illustration of repetition is Rychtařík's phrase slabost Dubčekova vedeni (the weakness of the Dubček leadership), cited 4 times in 13 lines. ${ }^{46}$ Reflexive verbs and the passive voice are exemplified, inter alia, by the expressions Bohužel, tyto naděje se nesplnily (Unfortunately these hopes [of a Leninist style of work] were not fulfilled), Doslovně se hazardovalo $s$ budoucností národa (The future of the nation was literally gambled with), and $A$ proto jsou tato fakta zamlčována či zkreslována (And therefore these facts [about wages outstripping the growth in productivity in 1968] are silenced or distorted). ${ }^{47}$ Nominalization is evidenced in convoluted sentences such as 'But most dangerous was the fact that, concurrent with the right's organizing [of itself] (organizování pravice), this [anti-socialist activity] was leading to the systematic paralyzing (ochromování) of the socialist state organs of power' [my italics]. ${ }^{48}$ However, occasionally the rigidity of the staged responses is mitigated by the introduction of a less formal and more impressionistic note: myslim si (I think), já vidím několik přičin (I can see several reasons), and podle mého názoru (in my opinion). ${ }^{49}$ The use of the first-person perspective, as would befit a forum of this type in a more open society, helps to promote a stronger illusion of polyglossia than had previously been the norm in Czechoslovakia. Even Party loyalists who shared the same views, and had a vested interest in maintaining the status quo, now appreciated the importance of creating the impression of a dialogue which allowed for at least some independent thought.

The round table serves to reaffirm the Party's bifurcate distinction between positive and negative. On the positive side in Legacy Corpus are terms such bolševismus (Bolshevism) and its cognates, cited 6 times; (Klement) Gottwald (Prime Minister of Czechoslovakia, 1946- 48, and President, 1948-53) and cognates, with 16 citations; jednota (unity) and jednotný (united), 42 citations; references to Lenin and Marx, including marxismus-leninismus (MarxismLeninism) and its derivatives, 92 citations; pevný (firm), upevnit (to strengthen) and cognates, 47; poctivý/poctivě (decent/decently), 43; princip/principiální (principle/ principled), 31; rozhodný/rozhodujicílrozhodně (decisive/decisively), 41; and zdravý (healthy), 14, used almost exclusively of adherents of the Party line. Negative expressions include antisocialistický/protisocialistický (antisocialist) and antisocialismus (antisocialism), 86;

\footnotetext{
${ }^{46}$ Černohorský and Kohout, 'Kulatý stůl',10.

${ }^{47}$ Černohorský and Kohout, 'Kulatý stůl', 8, 16, and 11.

${ }^{48}$ Černohorský and Kohout, 'Kulatý stůl', 14: Ale nejnebezpečnější bylo to, že souběžně s organizováním pravice docházelo $k$ systematickému ochromováni socialistických státnich mocenských orgánů.

49 Černohorský and Kohout, 'Kulatý stůl', 10 and 13.
} 

antikomunismus (anti-Communism), 33; destrukce (destruction) and cognates, 15 citations; demagogie (demagoguery) and cognates, 16; demontáž (dismantling), 9; dezorientovat (to disorientate) and derivatives, 9; kontrarevolucelkontrarevoluční (counter-revolution/counter-revolutionary), 66; nejednotný (disunited) and cognates, 7; neprátelé (enemies) and cognates, 24; oportunismus (opportunism) and cognates, 41; pravice (the right) and cognates, 256; revize/revizionismus (revision/revisionismus) and cognates, 50; subjektivní (subjective) and cognates, 17; Západ (the West) and cognates, 50; and živlylelementy (elements) and cognates, 25. A similar dichotomy also applies beyond the single-word level to collocations: délnické hnutí (workers' movement),6 citations; dělnická tř́lda (working class), 42; revoluční avantgarda/předvoj (revolutionary vanguard), 4; vs. antisocialistickélprotisocialistické živly/elementy (antisocialist elements), 7; antisocialistickélprotisocialistické sily (anti-socialist forces), 47; and pravicově oportunistický (right-wing opportunist), 15 (10 times in conjunction with síly).

In relative terms, there are fewer overtly negative referents in Legacy Corpus than in Poučen $i$ - for example, the citations for pravice (the right) and cognates equate to $389 \mathrm{ppm}$ and $1148 \mathrm{ppm}$, respectively. Moreover, Legacy Corpus pays slightly less attention than Poučeni to the mistakes of Communism, as reflected in the phrases nedostatky/nedostatečny' (shortcomings/inadequate), 35 citations or $53 \mathrm{ppm}$, vs. $94 \mathrm{ppm}$, and chyba/chybný/omyl (mistake/mistaken/error), 41 or $62 \mathrm{ppm}$, vs. $75 \mathrm{ppm}$. This may be partly attributable to the time that has elapsed since 1968, but it may also denote a subtle change in emphasis and tone. Whether or not Rudé právo was deliberating seeking to mitigate the failings of the past, the overall message is still that the interpretation of the Prague Spring and the ideology of the Party have not changed significantly. The validity of Communist dogma is reinforced by the repetition of several of the other buzzwords, such as boj (battle) and cognates, 95 citations; ideový (ideological) and cognates, 220; $K S \check{C}, 321$, including 170 times in the title $U^{\prime} V K S \check{C}$ (Central Committee of the KSČ); síla/síly (strength/forces), 113; strana (party) and derivatives, 766, or 1164 ppm, compared with 1786 ppm in Poučení, excluding uses where it means 'side' or 'hand'; and vedoucí, 94, including 67 times in the collocation vedoucí úloha (leading role). The sacred cows of Communism, particularly the leading role of the Party, the founding fathers of the socialist state and the Soviet model, remain immune from criticism. It is not by accident that strana is the most common non-function word in all three of the corpora consulted: Legacy Corpus, Poučení, and SKT.

The documents may seek to belie the declining legitimacy of the established order, but the very re-emergence of the Prague Spring as a topical discourse theme testifies to the intractability of the Party's problems. The contributors to Rudé právo clearly did not have any desire to push the bounds of the permissible, 
as had their predecessors two decades earlier, but they simply had no choice other than to respond to calls for more open dialogue, emanating from the easing of restrictions. They were faced with an insoluble, but delightfully paradoxical, dilemma: how to acknowledge the merits of glasnost/glasnost', cited 6 times (with variable spelling, which confirms its somewhat marginal status), and its more Czech-sounding equivalent informovanost (being informed), cited 10 times, whilst simultaneously circumscribing the semantic range and applications of these concepts. On the one hand, they could not ignore the parallels between Gorbachev's policies and the renewal of the 1960s; on the other, the mere act of denying the similarities invited more comparisons with the past, and further eroded the symbolism of the official word. The more they strove to counter alternative points of view, the more they engaged with, and thereby publicized and legitimized, the demands of the opposition. A significant part of this engagement entailed the adoption of terms of reference which did not conform to the approved semantic nomenclature. The Party had always had difficulties in imposing new meanings on established political concepts, not least because of Czechoslovakia's liberal democratic (or 'bourgeois') traditions, but the problems were compounded by the events of 1968. Until the mid-1980s, the Party managed the situation by largely confining discussion of the Prague Spring to the distortions of the Novotný era, Soviet friendship, and the importance of proletarian internationalism, as reflected in the headline article of Rudé právo on the tenth anniversary of the Warsaw Pact intervention. ${ }^{50}$ Obfuscatory and ideologically motivated expressions, such as krizové období (crisis period) and krizový stav (state of crisis), substituted for terminology more redolent of the positive spirit of revival.

By the late 1980s, it was impossible to talk about 1968 without at least acknowledging the vocabulary of the reform Communists, not least because this corresponded to the private usage of much of the general population. The dilemma for the hardliners was that after the Soviet occupation the official terms of reference smacked of perfidy and betrayal. The difficulties posed to the Party ideologues are perhaps best exemplified by Skalický's tortuous explanation of the differences in terminology, below. (In order to highlight the reform Communists' perspective on their role in the Prague Spring, semantically loaded terms that are not in inverted commas are glossed in square brackets.)

In their public appearances and the media, the spokesmen of the right [i.e. non-hardliners] hid behind demagogic slogans [i.e. used reformist phrases] such as 'socialism with a human face', 'democratic socialism' etc., and made themselves out to be [i.e. called themselves] 'progressives', whereas they abusively [i.e. correctly] called their opponents, the true supporters of socialism [i.e. Marxism-Leninism], 'conservatives', and ultimately began to slander [i.e.

${ }^{50}$ Unnamed eds, 'V zájmu socialismu, v zájmu našeho lidu’ (21 August 1978), 1-2. 
depict] them as 'traitors to the country'. They represented the retreat from socialism, its de facto dismantling, as the 'renovation' of socialism, as a 'new model' of socialism. ${ }^{51}$

Implicit in Skalický's comments is an acceptance that the official logocracy no longer enjoyed the same power as it had done previously. The words were the same, but their impact was diminished. The fact that he felt the need to reiterate the same metalinguistic points made in Poučeni seventeen years earlier confirms that the argument in favour of Normalization had been far from universally accepted.

The axiological contrast between the descriptors relating to the two opposing camps in the texts is striking. On the one side are the proponents of change, as reflected in terms such as progresivní (progressive) and its cognates, cited 9 times (5 times in inverted commas), and radikální (radical) and cognates, cited 14 times (6 times in inverted commas). On the other side are the supporters of Marxism-Leninism, as evidenced by lexical items such as dogmatický (dogmatic) and cognates, cited 18 times (3 times in inverted commas); konzervativní (conservative) and cognates, including twice in the slang form konzerva (conservative), cited 18 times (9 times in inverted commas); levice (the left) and cognates, cited 11 times; and sektářský (sectarian) and cognates, cited 6 times (once in inverted commas). ${ }^{52}$ The 14 citations of zrádce (traitor), zrádcový (treacherous), and zradit (to betray), 7 in inverted commas, and the 9 citations of kolaborant (collaborator) and kolaborace (collaboration), 7 in inverted commas, applied to the pro-Moscow stalwarts, are particularly telling, in view of the strong associations in Party mythology of the terms with the Munich 'betrayal' of 1938. (The lemmas Mnichov/mnichovský [Munich] and predmnichovský [preMunich] occur 16 times in Legacy Corpus.) Equally revealing are the phrases pražské jaro (Prague Spring), coined by Western journalists on the basis of the International Music Festival of the same name, and socialismus s lidskou tvár $r$ (socialism with a human face), which inevitably invited comparisons with really existing socialism. The former is cited 12 times: twice preceded by takzvanéltzv. (so-called), 9 times in inverted commas (including twice in the collocation 'muži pražského jara' ['the men of the Prague Spring']), and once in a quotation from Die Welt from 28 March 1968. ${ }^{53}$ The collocation s lidskou tvář́i (once preceded by obroditel [revivalist] and once by politika [politics]) appears 7 times, 3 times in inverted commas. Significant attention is also paid to the contentious

\footnotetext{
${ }^{51}$ Ladislav Skalický, 'Zamyšlení nad zasedáním ÚV KSČ před dvaceti lety: Leden a dnešek' (4 January 1988) (NS, 28-35 [p. 32]): 'Ve svých veřejných vystoupeních a ve sdělovacích prostředcích se mluvčí pravice maskovali demagogickými hesly typu „socialismus s lidskou tváŕí“, „demokratický socialismus“ apod., vydávali se za „progresivisty“, zatímco své odpůrce, věrné stoupence socialismu, hanlivě nazývali „,konzervativci“ a nakonec je začali pomlouvat jako „zrádce vlasti“. Ústup od socialismu, jeho faktickou demontáž vydávali za „obrodu“ socialismu, za „nový model“" socialismu'.

${ }^{52}$ Both 'levice' and 'pravice' are used pejoratively by supporters of the opposite sides, but 'levice' sometimes also had negative connotations for more pragmatic normalizers. See, for example, Lubomír Štrougal, Paméti a úvahy (Prague, 2009 ), 63 and 204.

${ }^{53}$ The functions of inverted commas and takzvané/tzv. are considered in detail in Dickins, 'The Impact Factor of the Language of Czechoslovak Normalization', 240-41.
} 
document Akční program - cited 18 times - which advocated a specifically Czechoslovak path to socialism. ${ }^{54}$ This reformist manifesto posed a particular problem to the Party in the late 1980s, since it had represented a compromise which remained attractive to many Czechs and Slovaks, especially erstwhile Party members.

The recognition of the 'new' realities drew greater attention to the existence of more specific ideological enemies. Amongst the hardliners' most problematic opponents were Alexander Dubček (First Secretary of the KSČ, from 5 January 1968 to 17 April 1969) and Václav Havel. Although Dubček is mentioned 33 times by name in Poučení, he had become virtually a non-person after the early 1970s, except in more specialized sources. This is borne out by $S K T$, in which citations of his name vary from none in 1952, to $68 \mathrm{ppm}$ in 1969, to just $5 \mathrm{ppm}$ in $1977 .{ }^{55}$ When Dubček was referred to explicitly, as in encyclopaedia entries, he was summarily dismissed in terms such as 'a representative of revisionism and right-wing opportunism' or 'the leading representative of the rightwing opportunistic forces in the Central Committee of the KSČ'. ${ }^{56}$ However, following his interview with the Italian newspaper L'Unità in January 1988, in which he likened Gorbachev's reforms to the Prague Spring, ${ }^{57}$ and his trip to Italy in November 1988, he could no longer simply be written out of history. The Party had to address the fact that an increasing number of people (especially exCommunists) were viewing him as a pioneer of prestavba. Note the title of the piece describing his trip to Italy, Na dotaz čtenářre [...] (In Answer to a Reader), which includes Jakeš's response to suggestions that Dubček might return to public life: 'Alexandra Dubčeka považujeme u nás za soukromou osobu' (We regard Alexander Dubček here as a private person). ${ }^{58}$ The dismissive and unpleasant tone of some of the comments relating to Dubček in Legacy Corpus illuminates the degree of concern at his reappearance: jak bývalý první tajemník ÚV strany Alexander Dubček krok za krokem ustupoval tlaku reakce (as former First Secretary of the Central Committee, Alexander Dubček yielded step by step to the pressure of reaction), Dubčekova ješitnost a samolibost (Dubček's vanity and smugness), nerozhodnost Alexandra Dubčeka (the indecisiveness of Alexander Dubček), and so on. ${ }^{59}$ Dubček is twice accorded the less than flattering epithet občan (citizen), which is juxtaposed with the title soudruh

\footnotetext{
${ }^{54}$ See, for example, 'Přestavba a Poučení z krizového vývoje: Alois Indra, člen předsednictva Ústředního výboru. KSČ, předseda Federálního shromáždění ČSSR' (NS, 163-74).

55 The treatment of Dubček in Poučení, written shortly after he had been ousted from power, is more circumspect because he was still very much in people's memory.

${ }^{56}$ See Unnamed eds, Malý slovník encyklopedický A-Ž (Prague, 1972), 265, and Bohumil Kvasil, et al., Malá československá encyklopedie, 6 vols (Prague, 1984 [A-Č], 1985 [D-Ch], 1986 [I-L], 1986 [M-Pol], 1987 [Pom-S], and 1987 [ك̌- Ž]), vol. 2, 213.

${ }^{57}$ Alexander Dubček and Renzo Foa, 'Alexander Dubcek «Mi sia restituito l'onore politico»', L'Unità, 10 January 1988, 15-18.

${ }^{58}$ Unnamed eds, 'Na dotaz čtenáře: K jedné soukromé cestě do Itálie’, 16 December 1988 (NS, 129-30 [p. 130]).

${ }^{59}$ Rudolf Vaněk, 'Má vzpomínka na rok 1968', 26 March 1988 (NS, 139); Milan Matouš, 'Dubčekova cesta od tragédie k frašce', 10 August 1988 (NS, 121-28 [p. 126]); and František Ráža, ‘Dnes jsou uraženi’, 17 August 1988 (NS, 142).
} 
(comrade), applied 13 times to Jakeš and 7 times to Husák. ${ }^{60}$ Only one contribution to Legacy Corpus - a piece by a certain Dr Kozel in April 1989 seeks to strike a slightly more nuanced approach to Dubček. The author, who had served with Dubček from 1968, but resigned from his role as a Party ideologist in January 1970, is unambiguously negative in his evaluation of his former leader's political skills and lack of experience, which he contrasts with those of the pre-war generation of Communists. But he adopts a softer attitude to Dubček as a human being, describing him as 'a kind and good-hearted person' (milý a dobrosrdečný člověk), who suffered the 'great human misfortune' (velké lidské neštěstí) of believing in his own 'exceptionality' (výjimečnost). ${ }^{61}$ Needless to say, kindness and good-heartedness are not personal attributes rated highly in the Communist world view.

An even more intractable set of problems was posed by Havel, who had stubbornly refused to abandon his native land in favour of exile. The Havel family name is referred to directly 46 times, compared with once in Poučení, while Charta 77 (Charter 77) and Výbor pro obranu nespravedlivě stíhaných (VONS) (The Committee for the Defence of the Unjustly Persecuted), with which he is inextricably linked, are cited 13 and 3 times, respectively. Havel's arguments are not specifically addressed, but, instead, the contributors employ abusive ad hominems to sully his personal reputation. The attack on Havel's bourgeois origins, in an unattributed piece, expands on the criticism of two earlier articles, which also allude negatively to his privileged background. ${ }^{62}$ The uncompromising nature of this contribution is worthy of note, especially in view of the date of its publication: late February $1989 .{ }^{63}$ The piece enumerates the supposed compromises made by his affluent forebears, including his grandfather's allegedly good relations with the Nazis, and his uncle's position as Rotary Club President, to suggest guilt by association. It then outlines Havel's own gradual anti-Communist progression, from his activities in 1968, to his defence of the Czech rock band, Plastic People of the Universe, with their vulgární texty (vulgar texts), to his role in the drafting of Charter 77, described pejoratively as a pamflet (pamphlet), ${ }^{64}$ to the defaming of Czechoslovakia abroad, and to his increasing anti-state activity, including the founding of VONS.

${ }^{60}$ Arnošt Bak and Jaroslav Kojzar, ‘Jak manipulují s... Alexandrem Dubčekem: Opravdu jen „mylná informace“?’, 16 July 1988 (NS, 119-20 [p. 119]); and Unnamed eds, 'Na dotaz čtenáře’ (NS, 128).

${ }^{61}$ Jaroslav Kozel, 'Strana vždy našla dost sil k zvládnutí nejsložitějších úkolů doby: Je čas se vyjádřit', 19 April 1989 (NS, 131-35 [pp. 132, 134]). The piece is also noteworthy for its superficial self-criticism.

62 Unnamed eds, 'Kdo je Václav Havel', 23 February 1989 (NS, 111-17). The earlier articles are: Unnamed eds, 'Ztroskotanci a samozvanci', Rudé právo, 12 January 1977, 2; and Václav Doležal, 'Tučná výslužka z Holandska', Rudé právo, 22 November 1986, 7 (not 22 November 1988, as stated in NS). The former of the two gave a particular political dimension to the terms ztroskotanci (down-and-outs) and samozvanci/samozvaný ([the] self-appointed), cited 8 times and 3 times, respectively, in Legacy Corpus.

${ }^{63}$ Havel had been imprisoned on 21 February 1989 for merely observing the demonstrations marking the anniversary of Palach's suicide.

${ }^{64}$ Věra Schmiedtová, Malý slovník reálií komunistické totality (Prague, 2012), 115, defines pamflet, in the context of Communist speak, as 'A defamatory leaflet, article, lampoon'. 
The authors argue that he wishes to return Czechoslovakia to a pluralist system (which he himself had stated in writing), with a view to reacquiring his family's former wealth (which was wholly disingenuous). They conclude caustically: "And so this is his concrete "model of the future": the First Republic [1918-38], the pre-Munich political regime'. ${ }^{65}$ The failure to present a detailed account of Havel's thinking is unsurprising, given that his views would have had a wider resonance than the Party line, but it also left the public demanding further information. Even Zdeněk Hoření, who played no small part in directing the campaign against Havel, subsequently claimed to have regretted that Rudé právo wrote about texts, such as Charter 77 and Několik vět, which were not in the public domain. ${ }^{66} \mathrm{~A}$ fellow (more forthright) former apparatchik, and head of the Ideological Department of the Central Committee, Jaroslav Jeník, went so far as to depict the invective against Havel and his family as clumsy and primitive. ${ }^{67}$

The attacks on dissident organizations were sometimes even more vitriolic. $\mathrm{K}$ 231 and KAN came in for particular criticism. Both were accused of nefarious plans to return Czechoslovakia to its pre-1938 status. For example, a piece in May 1988 refers to the principal representatives of K 231 as bývali agenti, špióni, organizátoři diverzí, ilegálních bojůvek (former agents, spies, organizers of diversionary activities and of illegal armed groups). ${ }^{68}$ The vocabulary could just as easily have been from the early 1950s as from the late Gorbachev period. The noun agent is cited 23 times in Legacy Corpus (including 3 times in the phrase agent-chodec [courier]); špión/špionáž (spy, espionage) and derivatives, 18 times; diverze (diversion) and cognates, 10 times; ilegální (illegal), 11 times; and bojuivy (commandoes), twice. The level of detail in the accounts of the opposition activities, such as the number of a bank account used by $\mathrm{K} 231$, is intended to impart authority to the descriptions. The texts themselves, which are unchallengeable in the absence of relevant alternative sources of information, contribute little of value to public knowledge ${ }^{69}$ Particular attention is paid to a K 231 operative, Otakar (Ota) Rambousek, who left Czechoslovakia in 1948, returned as an American agent, and re-emigrated after August 1968. ${ }^{70}$ The specifics of his anti-Communist escapades are of limited relevance here, but the lack of reference to his role in the Prague Uprising in May 1945, and to his 15 years in a Czech prison, constitute a striking omission from the account. Equally noteworthy is the discussion of a book by Rambousek, which happens to have recently fallen into the hands of one of the contributors (Nedávno se mi dostala

\footnotetext{
65 'Kdo je Václav Havel', 117: ‘To je tedy jeho konkrétní „model budoucnosti“‘: první republika, předmnichovský politický režim'.

${ }^{66}$ Vaněk and Urbášek, Vitězové? Poražení?, 138-71 (p. 164). On 28 January 1977, many leading names in Czech culture were asked to assemble in the National Theatre to the so-called Anti-Charter, 'For new creative activities in the name of socialism and peace', without having seen the original document.

67 Vaněk and Urbášek, Vitězové? Poražení?, 310-17 (p. 310).

${ }^{68}$ See Jaroslav Kojzar and Arnošt Bak, ‘„K 231“ Stahovat kůži zaživa...’, 21 May 1988 (NS, 78-82 [p. 79]).

${ }^{69}$ Ibid., 79.

${ }^{70}$ See František Vrbecký, 'Jeden z K 231', 13 August 1988 (NS, 83-86).
} 
do rukou kniha), despite being effectively banned by the authorities. ${ }^{71}$ The work, which comprises a series of stories told from the perspective of prisoners sentenced for spying, was produced by the reviled 68 Publishers in Toronto, and includes a number of descriptions in colloquial Czech, to which the reader apparently takes objection. ${ }^{72}$ Another contributor to Rudé právo picks up the thread, and asserts: 'The memory of those who fought on the side of the nascent socialist state cannot be sullied by people of such [low] moral and personal qualities as Rambousek and his ilk'. ${ }^{73}$

Other victims of the official opprobrium included the Union of Czechoslovak Writers, whose 'manifesto' in 1967 'constituted an inflammatory campaign against socialist Czechoslovakia' (posloužil ke štvavé kampani proti socialistickému Československu). The said manifesto was the proceedings of the Union's Fourth Congress in Prague from 27 June to 29 June 1967. ${ }^{74}$ Amongst the writers who contributed to this extraordinary cultural event were Eduard Goldstiucker (1913-2000), best known perhaps for his role in the rehabilitation of Franz Kafka in $1963 .{ }^{75}$ Goldstücker, who emigrated to Britain in 1968, is accused of manipulating 'radical' students, and of using 'sophisticated demagoguery' (rafinovaná demagogie) to charge 'conservatives' in the Party with anti-Semitic views. ${ }^{76}$ A further target of the Normalizers' censure was the prolific journalist and writer Ferdinand Peroutka (1895-1978), a supporter of Masaryk's 'Castle' group in the First Republic, who left Czechoslovakia in 1948, and directed the Czech section of Radio Free Europe from 1951 to 1961. Vaněk cites Peroutka's (seemingly) prophetic words about the legacy of Czech journalists in the aftermath of the Warsaw Pact occupation: 'I think that nothing will remain of our work, save for disgusting stains on the window, resembling those left by flies in the autumn'. ${ }^{77}$ Another individual singled out for strong criticism was Petr Uhl, a Trotskyist and co-founder of Charter 77. Kojzar accuses Uhl of demogogic misuse of the slogan samosprávná společnost (social selfgovernance), of working with the Fourth International, as well as with KOR (The Workers' Defence Committee) and Solidarity in Poland, and of employing 'pseudo-revolutionary phrases' (pseudorevolučni fráze) to conceal his aim of overthrowing the socialist estalishment. ${ }^{78}$

${ }^{71}$ Jiř́i Mikša, 'Ti z druhé strany: Krochnu s sebou!', 2 July 1988 (NS, 87-88 [p. 87]).

72 Ota Rambousek, Krochnu s sebou (Toronto, 1978).

${ }^{73}$ František Koranda, ‘Na dráze špióna: Jak to bylo s „krochnou“'?', 12 November 1988 (NS, 89-90 [p. 90]): 'Památka těch, kteří bojovali na straně rodícího se socialistického státu, nesmí být pošpiněna lidmi takových morálních a charakterových kvalit, jakými jsou Rambousek a jemu podobní'.

${ }^{74}$ Marie Boudová, 'Nezastíraný útok proti vedoucí úloze strany', 23 October 1987 (NS, 26-27 [p. 26]). For the proceedings of the Writers' Congress, see Otakar Mohyla, ed., IV. sjezd Svazu československých spisovatelů (Prague, 1968).

${ }^{75}$ Franz Kafka: Liblická konference 1963, ed. Eduard Goldstücker (Prague, 1963).

${ }^{76}$ Antonín Vaněk, 'Říkali si radikálové', 4 June 1988 (NS, 101-03 [p. 103]); and Jiří Stáno, 'Jak to předpověděl Ferdinand Peroutka: Skvrny jako po mouchách', 14 July 1988 (NS, 91-96 [p. 92]).

${ }^{77}$ Stáno, 'Jak to předpověděl Ferdinand Peroutka', 95: 'Myslím, že po nás nezůstane nic kromě odporných skvrn na okně, jež se podobají těm, které zůstávají na podzim po mouchách'. Little did Peroutka know that his contributions would once again inform Czech journalism after 1989.

${ }^{78}$ Jaroslav Kojzar, ‘Avanturista z tzv. Čtvrté internacionály: Pod maskou pseudorevoluční fráze’, 18 June 1988 (NS, 106-10). 
The reference to Trotskyism - a concept which was virtually taboo in the MarxistLeninist lexicon - is indicative of the limitations on the Party's ability to control the direction of political discourse.

The Communists' defamation of their adversaries was aimed in no small measure at distracting attention from their own failings. They had relatively little positive to proclaim for their 40 years in power, and much to conceal. For example, in 1990, GDP (in US dollars) per capita in Czechoslovakia was just 3563, compared with 21,481 in Austria and 21,301 in Germany, and male life expectancy was 67.63 years in the Czech Republic and

66.78 in Slovakia, compared with 72.47 and 72.08 in Austria and Germany. ${ }^{79}$ However, as long as they enjoyed a monopoly position, they could largely persist with their own representation of reality, irrespective of whether or not it was credible. Their constant evocation of the defining phenomena of the late 1960s was intended to reinforce the official interpretation of the past. Amongst the examples cited in Rudé právo were the all-state meeting (celostátní aktiv) of the Lidové milice (people's militia) in June 1968; the letter expressing loyalty to the Soviet Union, signed by 99 employees and family members of the Auto-Praga Factory in Vysočany (out of a total workforce of 4500!), and published in Pravda in July 1968; and the gathering of 'decent and honourable people' (poctivi a čestní lidé) (that is, hardliners) at the Lucerna Palace on 10 November $1968 .{ }^{80}$ Other selected moments in the rebuilding of monolithic socialism included the meeting of the Central Committee in November 1968, the publication of the Central Committee weekly ideological and political journal, Tribuna (1969-89), and the appointment of Husák as First Secretary in April 1969. ${ }^{81}$

By the late 1980s, the authority of the Party was so damaged that it increasingly sought to go beyond its traditional remit and to draw on additional sources of information to impart greater legitimacy to its diktats. Two methods employed to limited effect were the increased use of eye-witness accounts and references to non-Communist sources. The former consisted largely of the memories of readers who stuck loyally to the Party line. ${ }^{82}$ (Sadly, there is no record of letters sent to Rudé právo which deviated from this line.) None of the readers' letters presents much that is new, but the passion and more personalized

\footnotetext{
79 See 'Gross Domestic Product (GDP) in Czechoslovakia', 8 June 2012, accessed 1 October 2014, http://kushnirs. org/macroeconomics/gdp/gdp_czechoslovakia.html\#main 3; and Emil Ginter, Vladimir Simko, and Ladislava Wsolova, 'Fall of the Iron Curtain: Male Life Expectancy in Slovakia, in the Czech Republic and in Europe', Central European Journal of Public Health 17.4 (2009): 171-74 (p. 172), accessed 1 October 2014, http://apps.szu. cz/svi/cejph/archiv/2009-4-01-full.pdf.

${ }^{80}$ See especially Unnamed eds, 'Obrana i rozvoj socialismu - nedělitelný úkol', 19 August 1988 (NS, $203-12$ [p. 207]); Václav Pergl, 'Naše přátelství chráníme jako oko v hlavě', 16 August 1988 (NS, 47-50); and Marie Boudová, based on an account by Jarmila Pešková, 'Oslavy velkého října v pražské Lucerně před 20 lety: Sjednocování poctivých a čestných lidí', 16 November 1988 (NS, 51-53). The letter by the 99 Auto-Praga affiliates, ‘«Nashu druzhbu my khranim, kak zenitsu oka»’, Pravda, 30 July 1968,2 , was used as a pretext for military intervention.

${ }^{81}$ See Karel Horák, 'Nad rezolucí Listopadového zasedání ÚV KSČ v roce 1968: Důležitý mezník v boji o překonání krize’, 14 November 1988 (NS, 54-58); Miloslav Vítek, 'Před dvaceti lety začala vycházet Tribuna: Historie mluví k dnešku', 11 January 1989 (NS, 59-62); and Pergl, 'Naše přátelství chráníme', 50.

${ }^{82}$ See Vzpomínky čtenářu - pamétníkủ (NS, 137-60).
} 
nature of some of the contributions offers a degree of contrast to the dry, hectoring tone of the professional journalists. Typical is the short piece by Květoň, entititled Tak to citím já (That's what I feel), exhorting people to learn the lessons of 1968, which includes the phrases pro mnohé $z$ nás (for many of us), svým vlastním podpisem (with my own signature), and mrzi mne, že (I am sorry that). ${ }^{83}$ Květoň's letter concludes 'It is very $[\mathrm{moc}]$ necessary to explain, to inform, constantly to return to the essence of the crisis and, above all, to draw from it the correct conclusions for our policies today'. ${ }^{84}$ Note the rhetorical use of parallelism and the colloquialism moc. In a similarly informal stylistic vein is Holečková-Dolejšr's denunciation of the opposition's tactics during the Prague Spring, which includes the lines 'In August 1968, my husband and I, with our four-year-old granddaughter, were in a cottage near Benešov [Central Bohemia]. When we learnt about the international assistance of our allies, we breathed a sigh of relief' ${ }^{85}$

Amongst the themes to emerge from the personal accounts of the past are the gratuitous disrespect shown to Communist figureheads, such as ex-president Gottwald and the journalist and writer Julius Fučík; the lessons learnt from the old guard; the continued validity of Poučeni; resistance to reform Communism; threats, intimidation, and aggression against opponents of reform; and so forth. Particularly noticeable is the almost sycophantic veneration of the founding fathers of socialism, variously referred to as 'pre-war members of the KSĆ' (předváleční členové KSČ), 'older and merited [Party] members' (starši a zasloužilí členové), and 'steeled comrades' (zocelení soudruzi). ${ }^{86}$ The irony of the fact that the Stalinist policies of the erstwhile Party leadership had led to the imprisonment of their then president, Husák, as well as to the suffering of so many other senior Communists and sympathizers, and had been a major stimulus for the Prague Spring, was lost on the contributors. Like Husák himself, the letter writers willingly suspended disbelief, in the name of an ideology in which they had unquestioning faith.

The second technique used by the Party hacks to give a greater semblance of authority to their texts was to refer to a wider range of western, émigré and underground sources, either unavailable to the general public, or officially frowned upon by the state. These included, amongst others, the journals Aussenpolitik, Foreign Affairs, Life, and Svoboda; the newspapers Le Figaro, Literární noviny, The New York Times, and The Sunday Times; the international news agencies AFP, Reuters, and UPI; the broadcasters Austrian television

\footnotetext{
${ }^{83}$ Miloslav Květoň, 'Tak to cítím já', 17 August 1988 (NS, 143).

${ }^{84}$ Květon̆, 143: 'Vysvětlovat, informovat, stále se vracet k podstatě krize a hlavně z ní vyvozovat správné závěry pro naši dnešní politiku, to je moc potřebné'.

${ }^{85}$ Božena Holečková-Dolejší, 'Hrst vzpomínek na rok 1968', 14 May 1988 (NS, 153-55 [p. 154]): 'Byli jsme v srpnu 1968 s manželem a čtyřletou vnučkou v chatě blízko Benešova. Když jsme se dozvěděli o internacionální pomoci našich spojenců, oddychli jsme si'.

${ }^{86}$ Holečková-Dolejší, 'Hrst vzpomínek na rok 1968', 153; Zdeňka Kapuciána, recorded by Anna Dragounová, 'I v téhle zkoušce obstáli’, 23 April 1988 (NS, 156-58 [p. 158]); and Olga Simová, 'Za věrnost straně’, 17 August 1988 (NS, 144).
} 
(ORF), the BBC, and Svobodná Evropa; and books such as Ota Šik’s Třetí cesta (The Third Way), Jaroslav Brodský's Řešení gama (The Gamma Solution), and Petr Uhl's Program společenské samosprávy (The Programme of the SelfGoverning Society). For example, Kojzar writes at some length about Leon Trotsky's polemical work, The Permanent Revolution, while Matouš draws on the wisdom of Ota Šik to deride Dubček: 'O. Šik declared in an interview broadcast on the BBC on 13 December 1987 that "Dubček was weak and unable to lead, and devoid of his own views and convictions"" 87 The paradox of quoting Šik's opinions on Dubček, as mediated through the airwaves of the BBC, cannot have gone unnoticed by more perceptive readers. Nor could they have failed to appreciate the injustice of the journalists' privileged access to information. From the point of view of the Party propagandists, the dissemination of restricted knowledge was a double-edged sword. On the one hand, it enabled them to show their responsiveness to change, and their preparedness to extend the parameters of debate; on the other, it highlighted the existence of inaccessible alternative sources, and implicitly brought into question the credence of the existing canonical works.

\section{Concluding remarks}

Two apparently contradictory deductions can be made from the findings presented in this article. On the surface, nothing much had changed. The old guard was still firmly in control. It was prepared to countenance and even promote economic reform, but it was not willing to loosen its hold on power or to jeopardize the leading role of the Party. The content and the style of the ideology remained uncompromising. Communists were still depicted as poctiví lidé (the decent people) and čestní lidé (the honourable people) - phrases cited 10 times and 14 times, respectively - while the opposition was dismissed as pravicoví oportunisté (right-wing opportunists), nepřátelé (enemies), and worse. To all except the more astute observers, Czechoslovakia remained in the grip of hardline totalitarian rule. Yet, below the surface, something had shifted. A close reading of the contributions to Rudé právo shows that the Party was now on the defensive. Instead of setting and controlling the agenda, it was responding to external events. The invocation of the spirit of Poučeni may have appeared apposite in view of the twentieth anniversary of 1968, but it was necessitated by unwelcome comparisons between the Prague Spring and Gorbachev's reforms. People were still, of course, afraid of the security apparatus, but they were emboldened by developments throughout the Communist world, and increasingly rejected the official interpretation of reality. The 'coded' message of the approved discourse no longer held sway to the extent that it had in the past.

\footnotetext{
${ }^{87}$ Kojzar, 'Avanturista z tzv. Čtvrté internacionály’; and Matouš, 'Dubčekova cesta', 126: 'O. Šik prohlásil v rozhovoru vysílaném BBC 13. prosince 1987: „Dubček byl slabý, neschopný vést, bez vlastního názoru a přesvědčení“’.
} 
The contributors to Rudé právo had no option other than to respond in some measure to the transformation in the public mood, and to engage at some level with their opponents. This engagement included extending the range of legitimate themes for discussion, broadening the evidence base for their assertions, and allowing more accounts of personal experiences. It also involved a number of subtle changes in the use of language, including the introduction of expressions previously confined to the private sphere, such as disident/disidentský (once misspelt as desedent), cited 6 times. Greater recognition was likewise given to the contrast between the negative epithets applied by the opposition to the Communist leadership, such as dogmatici (dogmatists) and figuriny z panoptika (waxwork figures), and the more positive terms used of the reformers, such as obroditele (revivalists) and progresivisté (progressives). However, the more the Party apologists opened up dialogue and used their detractors' terms of reference, the more people craved greater freedom of information and rejected the prescriptiveness of the establishment. The success of the existing canonical discourse had been attributable to a combination of strict state control, fear, and public resignation, which were contingent on the continued adherence of the Soviet Union to the Brezhnev Doctrine. Once Gorbachev had rejected the principle of armed intervention in other socialist countries, Czechoslovakia no longer had any reason to defer to the Kremlin or to endorse Marxism-Leninism. The best that the supporters of Normalization could do was to adopt a kind of holding position in the hope that the political situation in the USSR would change in their favour.

This article has sought to show the difficulty for the Communist leadership of reconciling two antithetical versions of reality: one based on stability and continuity at all costs; the other on the need to embrace externally enforced change. The Party's insistence on superimposing its own ideological precepts of the past on its vision of the future rendered meaningful reform (even in the economic sphere) virtually impossible. The study contends that the tensions existing between the two diametrically opposed forces operating in politics were reflected, albeit marginally, in the rhetoric and argument of Rudé právo. It further maintains that the 'authoritative discourse' model represents a particularly useful analytical framework for evaluating the impact of ideological language in the context of the Communist system. The model asserts that the repetition of hypernormalized empty phrases can achieve a degree of social cohesion, based on acquiescence and passivity, as long as the ruling elite has the means to impose its a priori conceptions and policies on the population at large. As soon as alternative perspectives begin to inform the debate, the authority of the official word quickly breaks down, and demands for more substantive change become irresistible. The refusal of the Party to polemicize seriously with its opponents for so long might have seemed counter-productive to more liberal-minded Communists, but it almost certainly delayed the demise of the regime. 